\title{
A Short Review on Sleep Scheduling Mechanism in Wireless Sensor Networks
}

\author{
Zeyu Zhang ${ }^{1}$, Lei Shu ${ }^{1,2}$, Chunsheng Zhu ${ }^{3}$, and Mithun Mukherjee ${ }^{1}$ \\ 1 Guangdong Provincial Key Lab of Petrochemical Equipment Fault Diagnosis, \\ Guangdong University of Petrochemical Technology, China, 525000 \\ 2 School of Engineering, University of Lincoln, UK \\ 3 Department of Electrical and Computer Engineering, The University of British \\ Columbia, Canada \\ zeyu-zhang@outlook.com, lshu@lincoln.ac.uk, cszhu@ece.ubc.ca, \\ mithun.mukherjee@outlook.com,
}

\begin{abstract}
Sleep scheduling, also known as duty cycling, which turn$\mathrm{s}$ sensor nodes on and off in the necessary time, is a common train of thought to save energy. Sleep scheduling has become a significant mechanism to prolong the lifetime of WSNs and many related methods have been proposed in recent years, which have diverse emphases and application areas. This paper classifies those methods in different taxonomies and provides a deep insight into them.
\end{abstract}

Key words: Wireless Sensor Networks (WSNs), Sleep Scheduling, Duty Cycling

\section{Introduction}

In WSNs, most sensor nodes have to rely on unrechargeable power sources, e.g., batteries, to provide the necessary power. In most cases, it is difficult to charge or replace the batteries, especially in outdoor monitoring. Thus, their power management has become crucial. Energy shortage is always the bottleneck restricting the development of WSNs applications [1]. As an engineering practice, sleep scheduling or duty cycling approaches have long been used in a wide variety of devices to save energy and prolong the lifetime of equipments, such as airconditioning compressors, pumps and electric motors [2].

As for WSNs, most existing hardware, e.g., CC2420, can support several modes, i.e., transmission mode, idle mode and sleep mode [3]. The communicating radio circuitry is still turned on but will not transmit or receive data in the idle mode. The idle listening will drain as much as tens to thousands times the current consumed during the sleeping state [4], thus, the major goal of duty cycling or sleep scheduling mechanism is to reduce the idle state energy consumption on the condition of guaranteeing network connectivity. 


\section{Duty Cycling}

Duty cycle is the ratio between the wake up time length in a predefined period and the total length of the period [5], e.g., a period or a slot is $1 \mathrm{~s}$ and one node stays active for $0.1 \mathrm{~s}$ and sleeps for other $0.9 \mathrm{~s}$, the duty cycle is 0.1 .

Duty cycling mechanism can be classified into three categories commonly, i.e., synchronous wake-up methods, asynchronous wake-up methods, and semisynchronous wake-up methods, as shown in Fig.1.

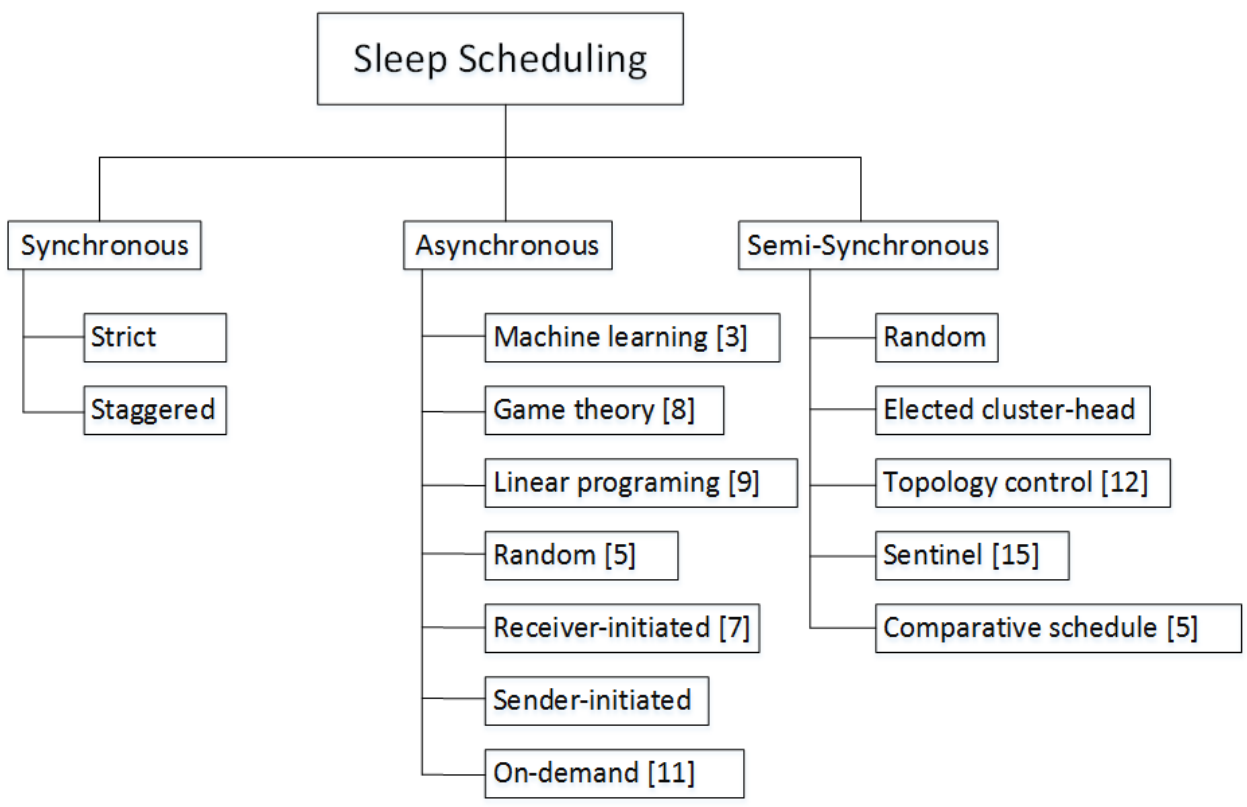

Fig. 1. The taxonomy for sleep scheduling methods

- Synchronous Schemes, In synchronous schemes, such as S-MAC [6], TMAC [7], sleeping nodes wake up at the same time periodically to communicate with one another, which means the networks have to keep a global synchronization. This kind of methods is intuitive and straightforward but requires synchronization mechanism which demands more extra control traffic.

- Semi-Synchronous Schemes, Semi-synchronous schemes, also known as cluster synchronization, such as [8-10], is a local synchronous method. In this method, sensor nodes are grouped into synchronized clusters. In the same cluster, sensor nodes wake up or go to sleep at the same time. But clusters act together with others asynchronously. Compared with synchronous schemes, group-synchronization is easier to achieve.

- Asynchronous Schemes, In asynchronous wake-up mechanisms, such as [1113], each node has its own wake-up and sleep schedule, which demands the 
wake-up slot should overlap among neighbors, or the message cannot be transmitted. To satisfy this requirement, the sensor nodes may have to wake up more frequently than in synchronous wake-up approaches.

\section{Recent research conclusion}

To the best of our knowledge, the most important survey of sleep scheduling is [4] in last four years, this section summarizes the main conclusions of papers published from 2015 to 2017, as shown in Table 1. From the table, we can see most papers focus on the asynchronous scheduling theory, less papers focus on the semi-synchronous theory. And machine learning is becoming the main trend of this field. We lists some potential directions below.

\section{Future directions}

Most papers and literature illustrate a clear trend of development in sleep scheduling algorithms, i.e., complexity and diversity. Sleep scheduling aims at maximizing the network lifetime, actually there exists several techniques that can do the same work.

1. Mobile relays and sinks, low duty-cycle can prolong the lifetime of WSNs, but can also bring about message missing or delivery delay. And the nodes around the sink node ran out of their energy quickly, which can lead to energy hole. Mobile relays and sinks can solve this kind of problem. The mobile sink, just like a mobile robot, can travel around to gather information, which offers a good trade-off between energy consumption, latency and delivery delay.

2. Clustering, clustering is the first step of most semi-synchronous theory. In this kind of methods, network is divided into several clusters, and cluster heads are responsible for communicating with other clusters. Actually, the cluster heads are always common nodes and have high duty cycle compared with other nodes. How to balance the energy consumption among them is very important in the future research.

3. Energy Harvesting, as a common train of thought to prolong the network lifetime, sleeping scheduling can only save energy but cannot generate energy. But the harvested energy is not stable and abundant. Thus, energy harvesting becomes another promising area to interact with sleep scheduling, which can solve the the problem of energy shortage to some degree.

4. Wireless charging, wireless charging provides a convenient, safe and reliable way to power electrical devices, which can become a dependable method to balance the energy consumption in the network. As we know, the nodes far away from the sink nodes are always responsible for collecting data and do not have to relay data, their energy will ran out at length. How to make most of the energy is very important for the lifetime of the network. 
5. Cloud computing, the cloud computing can be used to process the data collected from WSNs and share the results with mobile users, which is a promising orientation to collaborate with sleep scheduling.

6. Cross-layer designs, cross-layer designs try to exploit a more complicated interaction among communication layers to achieve better performance compared to the layered communication approaches which separate communication tasks within several layers. Extensive cooperation among layers can promote the energy efficiency in WSNs.

\section{Acknowledgments}

This work is supported by China Maoming Engineering Research Center on Industrial Internet of Things (No.517018) and major international cooperation projects of colleges in Guangdong Province (No.2015KGJHZ026) and Science and Technology Planning Project of Guangdong Province (No. 2017A050506057). Lei Shu is the corresponding author.

\section{References}

1. I. F. Akyildiz, W. Su, Y. Sankarasubramaniam, and E. Cayirci, "Wireless sensor networks: a survey," Computer networks, vol. 38, no. 4, pp. 393-422, 2002.

2. W. Ye, J. Heidemann, and D. Estrin, "An energy-efficient mac protocol for wireless sensor networks," in INFOCOM 2002. Twenty-First Annual Joint Conference of the IEEE Computer and Communications Societies. Proceedings. IEEE, vol. 3, pp. 1567-1576, IEEE, 2002.

3. T. Instruments, "Cc2420: 2.4 ghz ieee 802.15. 4/zigbee-ready rf transceiver," Available at Available at http://www. ti. com/lit/gpn/cc2420, vol. 53, 2006.

4. R. C. Carrano, D. Passos, L. C. Magalhaes, and C. V. Albuquerque, "Survey and taxonomy of duty cycling mechanisms in wireless sensor networks," IEEE Communications Surveys \& Tutorials, vol. 16, no. 1, pp. 181-194, 2014.

5. D. Ye and M. Zhang, "A self-adaptive sleep/wake-up scheduling approach for wireless sensor networks," IEEE Transactions on Cybernetics, 2017.

6. C. Zhu, Y. Chen, L. Wang, L. Shu, and Y. Zhang, "Smac-based proportional fairness backoff scheme in wireless sensor networks," in The International Wireless Communications and Mobile Computing Conference, pp. 138-142, 2010.

7. M. I. Khalil, M. A. Hossain, R. Mamtaz, I. Ahmed, and M. Akter, "Time efficient receiver oriented sleep scheduling for underwater sensor network," in Imaging, Vision 8 Pattern Recognition (icIVPR), 2017 IEEE International Conference on, pp. 1-6, IEEE, 2017.

8. D. Wang, M. Mukherjee, L. Shu, Y. Chen, and G. Hancke, "Sleep scheduling for critical nodes in group-based industrial wireless sensor networks," in Communications Workshops (ICC Workshops), 2017 IEEE International Conference on, pp. 694-698, IEEE, 2017.

9. W. Fang, M. Mukherjee, L. Shu, Z. Zhou, and G. P. Hancke, "Energy utilization concerned sleep scheduling in wireless powered communication networks," in Communications Workshops (ICC Workshops), 2017 IEEE International Conference on, pp. 558-563, IEEE, 2017. 
10. Y. Wang, H. Chen, X. Wu, and L. Shu, "An energy-efficient sdn based sleep scheduling algorithm for wsns," Journal of Network and Computer Applications, vol. 59, pp. 39-45, 2016.

11. J. Oller, I. Demirkol, J. Casademont, J. Paradells, G. U. Gamm, and L. Reindl, "Has time come to switch from duty-cycled mac protocols to wake-up radio for wireless sensor networks?," IEEE/ACM Transactions on Networking, vol. 24, no. 2, pp. 674-687, 2016.

12. S. B. Baba and K. M. Rao, "Improving the network life time of a wireless sensor network using the integration of progressive sleep scheduling algorithm with opportunistic routing protocol," Indian Journal of Science and Technology, vol. 9, no. $17,2016$.

13. H. P. Gupta, S. V. Rao, and T. Venkatesh, "Sleep scheduling protocol for $k$ coverage of three-dimensional heterogeneous wsns," IEEE Transactions on Vehicular Technology, vol. 65, no. 10, pp. 8423-8431, 2016.

14. M. Kordafshari, A. Movaghar, and M. Meybodi, "A joint duty cycle scheduling and energy aware routing approach based on evolutionary game for wireless sensor networks," Iranian Journal of Fuzzy Systems, vol. 14, no. 2, pp. 23-44, 2017.

15. H. Mostafaei, A. Montieri, V. Persico, and A. Pescapé, "A sleep scheduling approach based on learning automata for wsn partial coverage," Journal of Network and Computer Applications, vol. 80, pp. 67-78, 2017.

16. Z. Chen, A. Liu, Z. Li, Y.-j. Choi, and J. Li, "Distributed duty cycle control for delay improvement in wireless sensor networks," Peer-to-Peer Networking and Applications, vol. 10, no. 3, pp. 559-578, 2017.

17. S. Kumar and H. Kim, "Low energy scheduling of minimal active time slots for multi-channel multi-hop convergence wireless sensor networks," in Computing, Networking and Communications (ICNC), 2017 International Conference on, pp. 1051-1057, IEEE, 2017.

18. H. Chen, X. Li, and F. Zhao, "A reinforcement learning-based sleep scheduling algorithm for desired area coverage in solar-powered wireless sensor networks," IEEE Sensors Journal, vol. 16, no. 8, pp. 2763-2774, 2016.

19. R. Xie, A. Liu, and J. Gao, "A residual energy aware schedule scheme for wsns employing adjustable awake/sleep duty cycle," Wireless Personal Communications, vol. 90, no. 4, pp. 1859-1887, 2016.

20. Z.-Y. Xu, S.-G. Zhao, and Z.-J. Jing, "A clustering sleep scheduling mechanism based on sentinel nodes monitor for wsn," International Journal of Smart Home, vol. 9, no. 1, pp. 23-32, 2015. 
Table 1. Analysis of Existing Protocols With Respect to Different Sleep Scheduling

\begin{tabular}{|c|c|c|c|c|c|c|}
\hline Author & Key Issues & $\begin{array}{l}\text { Network } \\
\text { Structure }\end{array}$ & Energy & Solution & Advantages & Disadvantages \\
\hline $\begin{array}{l}\text { Kordaf- } \\
\text { shari et } \\
\text { al. [14] }\end{array}$ & $\begin{array}{l}\text { trade-off } \\
\text { between energy } \\
\text { conservation } \\
\text { and network } \\
\text { throughput }\end{array}$ & static & $\begin{array}{l}\text { non- } \\
\text { rechargeable } \\
\text { battery }\end{array}$ & $\begin{array}{l}\text { evolutionary } \\
\text { game theory }\end{array}$ & $\begin{array}{l}\text { achieve an } \\
\text { stable and } \\
\text { optimal } \\
\text { schedule }\end{array}$ & $\begin{array}{l}\text { serious } \\
\text { assumption and } \\
\text { slow } \\
\text { convergence }\end{array}$ \\
\hline $\begin{array}{l}\text { Ye et } \\
\text { al. }[5]\end{array}$ & $\begin{array}{l}\text { multi agent } \\
\text { non-cooperative } \\
\text { game }\end{array}$ & static & $\begin{array}{l}\text { non- } \\
\text { rechargeable } \\
\text { battery }\end{array}$ & $\begin{array}{l}\text { fussy logic and } \\
\text { Q-learning } \\
\text { algorithm }\end{array}$ & $\begin{array}{l}\text { dynamical } \\
\text { adjustment }\end{array}$ & $\begin{array}{l}\text { slow } \\
\text { convergence }\end{array}$ \\
\hline $\begin{array}{l}\text { Mosta- } \\
\text { faei et } \\
\text { al. [15] }\end{array}$ & $\begin{array}{l}\text { partial coverage } \\
\text { and preserve } \\
\text { connectivity }\end{array}$ & static & $\begin{array}{l}\text { non- } \\
\text { rechargeable } \\
\text { battery }\end{array}$ & $\begin{array}{l}\text { learning } \\
\text { automation }\end{array}$ & $\begin{array}{l}\text { adaptive } \\
\text { control, global } \\
\text { optimization } \\
\text { and good } \\
\text { robustness }\end{array}$ & $\begin{array}{l}\text { slow } \\
\text { convergence }\end{array}$ \\
\hline $\begin{array}{l}\text { Chen et } \\
\text { al. [16] }\end{array}$ & $\begin{array}{l}\text { reduce to-sink } \\
\text { data } \\
\text { transmission } \\
\text { delay while } \\
\text { lifetime is also } \\
\text { improved }\end{array}$ & static & $\begin{array}{l}\text { non- } \\
\text { rechargeable } \\
\text { battery }\end{array}$ & $\begin{array}{l}\text { comparison and } \\
\text { adaptation } \\
\text { duty-cycle } \\
\text { control }\end{array}$ & $\begin{array}{l}\text { dynamic } \\
\text { adjustment and } \\
\text { consider energy } \\
\text { hole }\end{array}$ & $\begin{array}{l}\text { lacks } \\
\text { comparison of } \\
\text { algorithms in } \\
\text { the same type }\end{array}$ \\
\hline $\begin{array}{l}\text { Kumar } \\
\text { et } \\
\text { al. [17] }\end{array}$ & $\begin{array}{l}\text { minimize the } \\
\text { active time } \\
\text { period of every } \\
\text { node }\end{array}$ & $\begin{array}{l}\text { multi-channel } \\
\text { and static }\end{array}$ & $\begin{array}{l}\text { non- } \\
\text { rechargeable } \\
\text { battery }\end{array}$ & $\begin{array}{l}\text { integer linear } \\
\text { programming }\end{array}$ & $\begin{array}{l}\text { less energy } \\
\text { consumption } \\
\text { and minimize } \\
\text { the network } \\
\text { latency }\end{array}$ & $\begin{array}{l}\text { hard handoff of } \\
\text { channel cause } \\
\text { ping-pong effect }\end{array}$ \\
\hline $\begin{array}{l}\text { Wang } \\
\text { et } \\
\text { al. [8] }\end{array}$ & $\begin{array}{l}\text { critical nodes } \\
\text { sleep scheduling }\end{array}$ & $\begin{array}{l}\text { grouped and } \\
\text { static }\end{array}$ & $\begin{array}{l}\text { non- } \\
\text { rechargeable } \\
\text { battery }\end{array}$ & $\begin{array}{l}\text { depth first } \\
\text { search-based } \\
\text { algorithms and } \\
\text { k-means cluster } \\
\text { algorithm }\end{array}$ & $\begin{array}{l}\text { maintain group- } \\
\text { connectivity }\end{array}$ & $\begin{array}{l}\text { not consider } \\
\text { network latency }\end{array}$ \\
\hline $\begin{array}{l}\text { Mukher- } \\
\text { jee et } \\
\text { al. [9] }\end{array}$ & $\begin{array}{l}\text { a trade-off } \\
\text { between energy } \\
\text { harvesting and } \\
\text { data } \\
\text { transmission }\end{array}$ & $\begin{array}{l}\text { static, } \\
\text { multi-sink, and } \\
\text { tree-based }\end{array}$ & $\begin{array}{l}\text { rechargeable } \\
\text { battery and } \\
\text { solar energy }\end{array}$ & $\begin{array}{l}\text { comparative } \\
\text { and random } \\
\text { scheduling }\end{array}$ & $\begin{array}{l}\text { intuitive, lower } \\
\text { control } \\
\text { overhead and } \\
\text { avoid energy } \\
\text { hole }\end{array}$ & $\begin{array}{l}\text { more complex } \\
\text { hardware and } \\
\text { not consider } \\
\text { networking } \\
\text { network latency }\end{array}$ \\
\hline $\begin{array}{l}\text { Khalil } \\
\text { et } \\
\text { al. [7] }\end{array}$ & $\begin{array}{l}\text { energy hole and } \\
\text { data recovery }\end{array}$ & $\begin{array}{l}\text { mobile, tree } \\
\text { topology }\end{array}$ & $\begin{array}{l}\text { non- } \\
\text { rechargeable } \\
\text { battery }\end{array}$ & $\begin{array}{l}\text { received } \\
\text { oriented } \\
\text { method based } \\
\text { on TDMA }\end{array}$ & $\begin{array}{l}\text { no data } \\
\text { collision and } \\
\text { save transaction } \\
\text { time }\end{array}$ & $\begin{array}{l}\text { prone to cause } \\
\text { energy hole }\end{array}$ \\
\hline $\begin{array}{l}\text { Chen et } \\
\text { al. [18] }\end{array}$ & $\begin{array}{l}\text { desired area } \\
\text { coverage and } \\
\text { energy } \\
\text { consumption } \\
\text { balance }\end{array}$ & static & $\begin{array}{l}\text { rechargeable } \\
\text { battery and } \\
\text { solar energy }\end{array}$ & $\begin{array}{l}\text { reinforcement } \\
\text { learning }\end{array}$ & $\begin{array}{l}\text { dynamic } \\
\text { scheduling and } \\
\text { high coverage } \\
\text { ratio }\end{array}$ & $\begin{array}{l}\text { high cost for } \\
\text { hardware and } \\
\text { not comparing } \\
\text { with other } \\
\text { energy } \\
\text { harvested } \\
\text { algorithms }\end{array}$ \\
\hline $\begin{array}{l}\text { Xie et } \\
\text { al. [19] }\end{array}$ & $\begin{array}{l}\text { a trade-off } \\
\text { among the } \\
\text { lifetime of } \\
\text { network, } \\
\text { transmission } \\
\text { delay and } \\
\text { packet loss ratio }\end{array}$ & static & $\begin{array}{l}\text { non- } \\
\text { rechargeable } \\
\text { battery }\end{array}$ & $\begin{array}{l}\text { based on } \\
\text { residual energy }\end{array}$ & $\begin{array}{l}\text { adjustable } \\
\text { schedule }\end{array}$ & $\begin{array}{l}\text { not considering } \\
\text { network latency }\end{array}$ \\
\hline $\begin{array}{l}\text { Mukher- } \\
\text { jee et } \\
\text { al. }[9]\end{array}$ & $\begin{array}{l}\text { maintain the } \\
\text { network } \\
\text { connectivity }\end{array}$ & $\begin{array}{l}\text { software defined } \\
\text { network (SDN) } \\
\text { and static }\end{array}$ & $\begin{array}{l}\text { non- } \\
\text { rechargeable } \\
\text { battery }\end{array}$ & $\begin{array}{l}\text { SDN-ECCKN } \\
\text { algorithm }\end{array}$ & $\begin{array}{l}\text { energy } \\
\text { management } \\
\text { and low faulty } \\
\text { ratio }\end{array}$ & $\begin{array}{l}\text { not considering } \\
\text { network latency }\end{array}$ \\
\hline $\begin{array}{l}\text { Oller et } \\
\text { al. }[11]\end{array}$ & $\begin{array}{l}\text { decrease degrees } \\
\text { of overhearing } \\
\text { and idle } \\
\text { listening }\end{array}$ & static & $\begin{array}{l}\text { non- } \\
\text { rechargeable } \\
\text { battery }\end{array}$ & wake-up radio & $\begin{array}{l}\text { reduce } \\
\text { unnecessary } \\
\text { energy waste, } \\
\text { e.g., idle } \\
\text { listening }\end{array}$ & $\begin{array}{l}\text { add extra } \\
\text { hardware }\end{array}$ \\
\hline $\begin{array}{l}\text { Baba et } \\
\text { al. }[12]\end{array}$ & $\begin{array}{l}\text { improve the } \\
\text { energy } \\
\text { efficiency }\end{array}$ & static & $\begin{array}{l}\text { replaceable } \\
\text { battery }\end{array}$ & $\begin{array}{l}\text { progressive } \\
\text { sleep scheduling } \\
\text { and } \\
\text { opportunistic } \\
\text { routing }\end{array}$ & $\begin{array}{l}\text { less energy } \\
\text { overhead and } \\
\text { increase the } \\
\text { routing quality }\end{array}$ & $\begin{array}{l}\text { not considering } \\
\text { communication } \\
\text { collision and } \\
\text { energy hole }\end{array}$ \\
\hline $\begin{array}{l}\text { Gupta } \\
\text { et } \\
\text { al. [13] }\end{array}$ & $\begin{array}{l}\text { minimize the } \\
\text { number of } \\
\text { active nodes in } \\
\text { a field of } \\
\text { interest }\end{array}$ & $\begin{array}{l}\text { three } \\
\text { dimensions and } \\
\text { static }\end{array}$ & $\begin{array}{l}\text { non- } \\
\text { rechargeable } \\
\text { battery }\end{array}$ & $\begin{array}{l}\text { estimate the } \\
\text { probability of a } \\
\text { sensor being } \\
\text { redundant }\end{array}$ & $\begin{array}{l}\text { lower energy } \\
\text { waste and } \\
\text { maintain } \\
\text { sensing coverage }\end{array}$ & $\begin{array}{l}\text { not considering } \\
\text { network latency }\end{array}$ \\
\hline $\begin{array}{l}\mathrm{Xu} \text { et } \\
a l .[20]\end{array}$ & $\begin{array}{l}\text { make some } \\
\text { nodes sleep and } \\
\text { maintain } \\
\text { monitoring } \\
\text { accuracy }\end{array}$ & $\begin{array}{l}\text { clustering and } \\
\text { static }\end{array}$ & $\begin{array}{l}\text { non- } \\
\text { rechargeable } \\
\text { battery }\end{array}$ & $\begin{array}{l}\text { sentinel nodes } \\
\text { and select the } \\
\text { cluster head } \\
\text { randomly }\end{array}$ & $\begin{array}{l}\text { effectively } \\
\text { balance the } \\
\text { energy } \\
\text { consumption } \\
\text { and extend } \\
\text { network lifetime }\end{array}$ & $\begin{array}{l}\text { sentinel nodes } \\
\text { run out of } \\
\text { energy quickly }\end{array}$ \\
\hline
\end{tabular}

